\title{
Structural, Anatomy Characteristics and Thermal Properties of Ampelodesmos mauritanicus (Diss)
}

\section{Chenah May* and Amrani Moussa}

Laboratory of Soft Technology, Valorization, Physico Chemistry of Biological

Materials and Biodiversity, Faculty of Science, M'Hamed Bougara University of

Boumerdes, Algeria

*Corresponding Author: Chenah May, Laboratory of Soft Technology, Valorization, Physico Chemistry of Biological Materials and Biodiversity, Faculty of Science, M'Hamed Bougara University of Boumerdes, Algeria.

DOI: 10.31080/ASAG.2020.04.0779
Received: December 30, 2019

Published: January 22, 2020

(C) All rights are reserved by Chenah May and Amrani Moussa.

\begin{abstract}
The structure, anatomical characteristics and thermal properties of the plant ampledosmos mauriatnicus were analyzed. The analysis of mineral compounds was carried out by X-ray fluorescence (FRX). Physical properties were investigated by Fourier Transform Infrared Spectroscopy (FTIR), X-ray diffraction and Thermogravimetric analysis (TGA). Scanning electron microscopy (SEM) was used to investigate the structure and morphology of sample. The results reveal the \% (W/W) cellulose content of Diss is $28.13 \%$, hemicelluloses content is $26.26 \%$ and lignin content is $24.95 \%$. Analysis of extractives contents in Diss were revealed to be $12.03 \%$. According to XRD data, Diss showed, a crystallinity index (CI) $52.5 \%$. High crystallinity of cellulose induces thermal decomposition of fibers at high temperatures. These results show that this plant is rich in cellulosic fibers and that could be used as raw material in industries and paper making.

Keywords: Ampelodesmos mauritanicus; Cellulose; Hemicellulose
\end{abstract}

\section{Introduction}

In recent years, more attention has been given to lignocellulosic biomass for sustainable development and environmental preservation [1-3]. Studies focusing on lignocellulosic biomass are increasingly important in view of the various applications [4-7]. The main biomass compounds are cellulose; hemicellulose and lignin. Hemicelluloses and cellulose are polysaccharides. Lignin is made of phenolic polymers that consist of three types of phenylpropaneuntis: p-coumaryl alcohol, coniferyl alcohol, and sinapyl alcohol [8-10]. Cellulose is a polymer of beta-D-glucopyranose moieties linked via beta- glycosidic bonds [11,12]. The cellulosic chains have a variable degree of polymerization between 10000 units of glucopyranose in wood to 15000 units in native cotton [13-15]. The properties of cellulose depend on several parameters such as chain length, crystallinity, hydrogen bonds and the distribution of functional groups [8-16-18]. These important parameters make cellulose a unique material. Therefore, one of the most important sources of cellulose remains wood, however the use of annual plants can be used. Increasingly, annual plants are being used as a potential source for industrial processing. These plants are interesting because of their abundance and low cost and their main advantage is their rapid growth which makes them available in many regions of the world [19-21]. Annual plants, Diss (Ampelodesmos mauritanicus), can be also used as an alternative to wood for cellulose-based materials. This plant species belongs to the poaceae, is found in the Mediterranean and resists drought well [2226]. To appreciate the potential of this plant, a physical, chemical, structural and thermal characterization is necessary. The aim of this work was to characterize the structural fibers of Diss from the north east of Boumerdes in Algeria by using Fourier transform infrared (FTIR) to determine the functional groups present in plant, $\mathrm{X}$-ray fluorescence (XRF) to estimate the quantity of elemental oxides, X-ray diffraction (XRD) to determine the degree of crystallinity in the plant, thermogravimetric analysis (TGA) of the thermal properties of the plant and scanning electron microscopy (SEM) to investigate the structure and morphology of the plant.

\section{Materials and Methods \\ Materials}

The stems of the "Diss" plant were harvested in the Boumerdes region of Algeria, the stems were rinsed with water to remove impurities. The stems were crushed until a homogeneous vegetable powder was obtained and was conserved from light and humidity.

\section{Methods}

\section{Extractives}

A $2.5 \mathrm{~g}$ sample of the vegetable powder of Diss previously prepared was put in a cellulose cartridge which will be extracted with Soxhlet with $150 \mathrm{ml}$ of solvent composed of a mixture of toluene and ethanol with a ratio of 2:1. The extraction at the Soxhlet lasts 6 hours. After extraction; the sample is dried at $105^{\circ} \mathrm{C}$ and the weight difference between the sample before and after extraction represents the extractives content [27].

\section{Lignin}

$3 \mathrm{~g}$ of the vegetable powder were put in glass test tubes with $30 \mathrm{ml}$ of $1.5 \%$ dilute sulfuric acid with stirring at $30 \mathrm{mn}$ intervals 
for $150 \mathrm{mn}$. After the initial hydrolysis, $10 \mathrm{ml}$ of distilled water was added. The tubes are autoclaved at $121^{\circ} \mathrm{C}$ for 1 hour for a second hydrolysis. After autoclaving, the mixture was filtered under vacuum and the residue was dried at $105^{\circ} \mathrm{C}$ to determine the amount of lignin insoluble in acid. Acid soluble lignin was determined by absorbance at $205 \mathrm{~nm}$. Total lignin was the sum of soluble and insoluble lignin [28].

\section{Hemicelluloses}

$1 \mathrm{~g}$ of vegetable powder of Diss was mixed with $150 \mathrm{ml}$ of $\mathrm{NaOH}$ $(0.5 \mathrm{~mol} / \mathrm{L})$ in a $250 \mathrm{ml}$ Erlenmeyer flask to boil them with distilled water for $3.5 \mathrm{~h}$. the mixture was vacuum filtered and washed to neutral $\mathrm{pH}$. The powder residue was dried at $105^{\circ} \mathrm{C}$. The hemicellulose content $(\% \mathrm{w} / \mathrm{w})$ was calculated by the difference in weight between the sample before and after treatment [28].

\section{Cellulose}

The cellulose content was determined using the Kurschner Hoffner approach. $5 \mathrm{~g}$ of the vegetable powder of the Diss previously extracted from its extractives were mixed with $125 \mathrm{ml}$ of the alcoholic nitric acid solution composed of one volume of $65 \%$ nitric acid and four volumes of $96 \%$ ethanol; the extraction is carried out by reflux for 1 hour (four cycles). Nitric acid is renewed at each cycle. At the end of the experiment, the cellulose was washed and dried [29].

\section{Analysis by X-ray fluorescence spectrometry}

$\mathrm{X}$-ray fluorescence spectrometry is an overall elemental analysis technique that identifies and determines most of the chemical elements that make up a sample. The analyzes of the plant powders were carried out by X-ray fluorescence (XRF) on the PHILIPS PW 1480 spectrometer with a dispersive technical wavelength. Before the chemical analysis, each sample was heated to $1000^{\circ} \mathrm{C}$ for 2 hours, and the decrease in mass was taken as loss during ignition.

\section{Analysis by Fourier Transform Infrared Spectroscopy (FTIR)}

The plant powder was analyzed by infrared (IRTF), using a "Bruker Thermo Scientific Waltham, MA, USA" spectrometer, by preparing $\mathrm{KBr}$ pellets containing $1 \%$ by weight of the plant powder. The spectra were recorded between 400 and $4000 \mathrm{~cm}-1$ at a resolution of $4 \mathrm{~cm}^{-1}$. The recorded spectra are the average of 32 scans.

\section{X-ray diffraction analysis (DRX)}

The plant powder samples were scanned for the wave number 0 $-4000 \mathrm{~cm}^{-1}$ and degree $2 \theta\left(0-50^{\circ}\right)$. The X-ray diffractometer used is of the D8 Advance BRUKER type, using monochromatic Kalpha1 radiation of copper (CuK $\alpha$-radiation) $(\lambda=0.154 \mathrm{~nm})$ at $45 \mathrm{kV}$ and continuous scanning. In order to determine the degree of crystallinity of the cellulose, the crystallinity index was determined by the empirical method of the height of the DRX peak developed by Segal., et al. [30] which examines the DRX spectra. The crystallinity index (CI) was calculated from the ratio of the peak height of 002 (I002) to the height of the minimum value (IAM) between 002 and the tips 101, using equation (1).

$\mathrm{CI}=(\mathrm{I002}-\mathrm{IAM}) / \mathrm{I002}) \times 100$

CI: Crystallinity Index

I002: Maximum intensity of the diffraction peak

IAM: Intensity diffused by the amorphous phase of the sample

\section{Thermogravimetric analysis (TGA)}

The combustion performance of Diss was monitored with a thermogravimetric analyzer (SDT Q600 - TA instrument). To know the temperature where devolatilization occurs, we measure the mass loss of the Diss sample during the combustion of the material. The sample was heated at temperatures ranging from $50^{\circ}$ The recording of the temperature measurements and the time degradation of the sample for the two analyzes TGA and DTG are done at the same time. The amount of powder sample used in this analysis is $4 \mathrm{mg}$.

\section{Scanning electron microscopy}

This technique capable of producing images of the surface of the studied sample using the principle of electron-matter interactions. The apparatus used is a scanning electron microscope of the FEI Quanta 650 type which makes it possible to analyze nonconductive samples such as plants, operating at $30 \mathrm{kV}$. The micrographs obtained make it possible to observe the microstructure of the surface of the vegetable powder.

\section{Results and Discussion}

Mineral composition

Several factors influence the concentration of a mineral compound in a plant such as the development stage, growth phase and age of the plant. Mineral compounds vary significantly depending on soil and climatic conditions [31]. According to the results of the FRX, the majority mineral element was silica with a content of $13.77 \%$. This result is in agreement with that found from MacManus., et al. (1977) in grass plants.

\begin{tabular}{|l|c|c|c|c|c|c|c|c|c|c|c|}
\hline \multirow{3}{*}{ Sample } & \multicolumn{10}{|c|}{ Mineral composition (\%) } \\
\cline { 2 - 12 } & $\mathbf{S i O}_{2}$ & $\mathbf{A l}_{2} \mathbf{O}_{3}$ & $\mathbf{F e}_{2} \mathbf{O}_{3}$ & $\mathbf{C a O}$ & $\mathbf{M g O}$ & $\mathbf{N a}_{2} \mathbf{0}$ & $\mathbf{K}_{2} \mathbf{O}$ & $\mathbf{T i O}_{2}$ & $\mathbf{M n O}$ & $\mathbf{P}_{2} \mathbf{O}_{5}$ & $\mathbf{S O}_{3}$ \\
\hline Diss & 13.77 & $<0.05$ & 0.09 & 1.21 & 0.97 & 1.47 & 3.5 & $<0.05$ & $<0.05$ & 0.13 & 0.97 \\
\hline
\end{tabular}

Table 1: Mineral Composition of Diss Sample (\% W/W).

\section{Chemical composition}

Table 2 shows the results of the different chemical compounds in the sample. The ash content was $8.63 \%$, a high content as is the case for all non-wood raw materials. The result obtained for the ash content was adequate with what was observed for stalk fibers by Hurter (1988) [32].
The percentage of the The Küschner-Hoffer cellulose was at a satisfactory level (28.13\%), it is advantageous for the pulp and paper industry because it yield higher pulp content after cooking process. The first fiber components responsible for the behavior of initial thermal degradation and associated with the moisture content 
are hemicelluloses. The Diss fibers had the total lignin (Klason and acid soluble lignin) content with around $24.95 \%$. The lignin content of the Diss sample is $24.95 \%$, a content slightly lower than that found in wood (25-37\%) [33,34]. According to Table 2, the amount of total extractive was found $12.03 \%$. The extractives content was $12.03 \%$ (Table 2), this content is similar to the content found in tropical woods (Dipteryx odorata and Mezilaurus itauba) [33].

\begin{tabular}{|l|c|c|c|c|c|c|c|c|}
\hline \multirow{2}{*}{ Sample } & \multicolumn{8}{|c|}{ Compositional Analysis of Diss (\% W) } \\
\cline { 2 - 9 } & Moisture & Minerals matter & Organic matter & Extractives & Klason Lignin & Acid soluble lignin & Hemicellulose & Cellulose \\
\hline Diss & 12 & 8.63 & 91.37 & 12.03 & 22.08 & 2.87 & 26.26 & 28.13 \\
\hline
\end{tabular}

Table 2: Compositional Analysis of Diss (\% W/W).

\section{FT-IR spectra}

Figure 1 shows the FTIR spectra of the Diss sample. The results show:

- A wide band at $3400 \mathrm{~cm}^{-1}$ relating to the $\mathrm{O}-\mathrm{H}$ stretching modes.

- Two bands at 2920 and $2850 \mathrm{~cm}^{-1}$ relating to the asymmetric and symmetrical methyl and methylene stretching groups present in the spectrum of all the components of the Diss sample. This is due to the high content of extractives which are represented by fatty acid methyl esters and phenolic acid methyl esters $[35,36]$.

- A band at $1800-1500 \mathrm{~cm}^{-1}$ relating to the lignin network [37].

- A band at $1730 \mathrm{~cm}^{-1}$ relates to hemicelluloses (acetyl group) and to lignin (uronic ester or to the carboxylic ester group of the ferulic cycle and of p-coumaric acid).

- Two bands at $1552 \mathrm{~cm}^{-1}$ and $1514 \mathrm{~cm}^{-1}$ are assigned to the groups $\mathrm{C}=\mathrm{C}$ and $\mathrm{C}-\mathrm{O}$ present in lignin [38].

- A band at $1200-900 \mathrm{~cm}^{-1}$ assigned to the polysaccharides is strongly intense proves that the polysaccharides in the sample are present in large quantities.

- A band at $1040 \mathrm{~cm}^{-1}$ is due to the group C-OH

- A band at $1159 \mathrm{~cm}^{-1}$ is allocated to the vibration C-O-C [33] and

- A peak at $896 \mathrm{~cm}^{-1}$ due to the $\mathrm{C}-\mathrm{H}$ deformation of the cellulose [39].

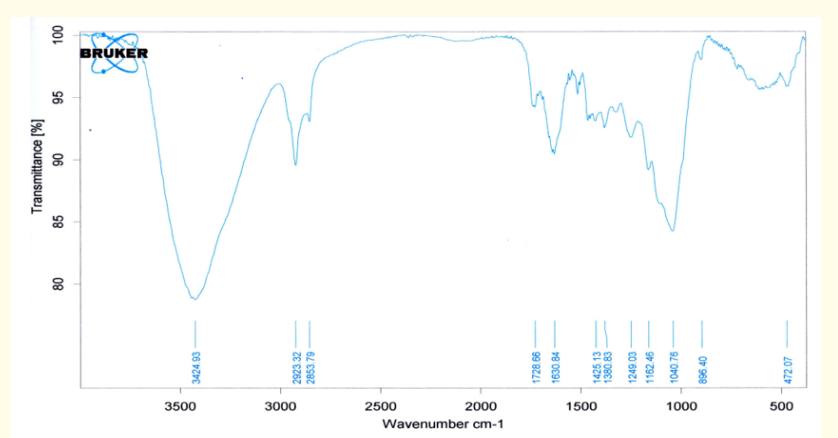

Figure 1: FTIR of Diss.

\section{X-ray diffraction}

The XRD results are summarized in Figure 2. From these results it is observed that the peak 002 is of an asymmetrical shape. According Wada and Okano (2001), the $2 \theta=22^{\circ}$ and the $2 \theta=14.6^{\circ}$ reflection assigned to the (002) and (110) crystallographic plan of cellulose, and the $2 \theta=18^{\circ}$ reflection assigned to the (110) amorphous phase.

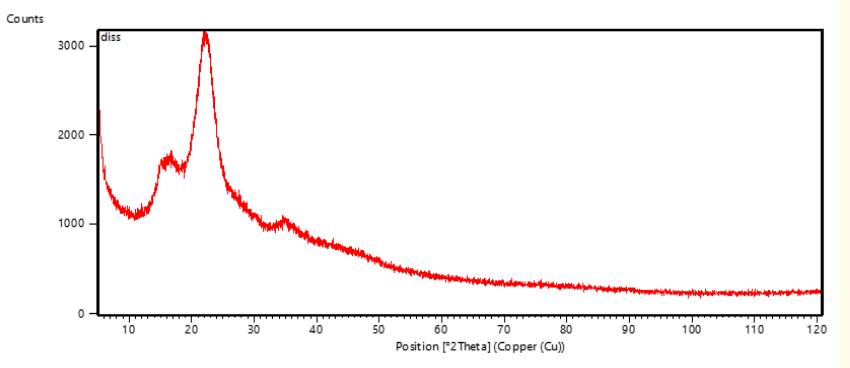

Figure 2: XRD diffractogram of Diss.

The crystallinity is influenced by the compounds of the raw material such as cellulose, hemicellulose and lignin which vary according to the botanical nature of the plant [40]. The crystallinity index was obtained from the ratio between the intensity of the 002 peak $\left(2 \theta=22^{\circ}\right)$ and the minimum intensity diffraction $\left(2 \theta=18^{\circ}\right)$ according to the Segal., et al. (1959) equation (1) [30]. The results show that crystallinity of the Diss was high, as presented in table 3. These results indicate that Diss contains a ordered cellulose structure [41].

\begin{tabular}{|c|c|c|c|}
\hline Sample & 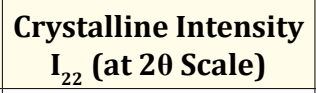 & 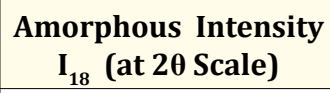 & $\begin{array}{c}\text { CI } \\
(\%)\end{array}$ \\
\hline Diss & 3178 & 1508 & 52,5 \\
\hline
\end{tabular}

Table 3: Crystallinity Index of Diss Based on XRD. CI : Crystallinity Index.

Thermogravimetric analysis

The pyrolytic behavior of the fibers in the sample was evaluated. The results of TGA and DTG of Diss are shown in figure 3. The results of TGA weight loss in three stages and decomposition in two. An initial weight loss at a temperature of $192.54^{\circ} \mathrm{C}$ evaluated at $5.28 \%$ due to the volatilization of humidity and low molecular weight compounds. A $23.57 \%$ weight loss due to the decomposition of hemicelluloses around the degradation temperature of the first stage $\mathrm{T} 1$ from $192.54^{\circ} \mathrm{C}$ to $280.12^{\circ} \mathrm{C}$. The second stage thermal degradation temperature, $\mathrm{T} 2$ around $280.12^{\circ} \mathrm{C}$ to $390.01^{\circ} \mathrm{C}$, corresponds to $47.29 \%$ of weight loss of cellulose and lignin present in the Diss. Between $390^{\circ} \mathrm{C}$ and $800^{\circ} \mathrm{C}$, a weight loss of $23.86 \%$ due to the degradation of lignin was observed. The hemicelluloses depoly- 
merize between $180^{\circ} \mathrm{C}$ and $350^{\circ} \mathrm{C}$, the glycosidic bonds of cellulose between $275^{\circ} \mathrm{C}$ and $350^{\circ} \mathrm{C}$ and the lignine degrades between $250^{\circ} \mathrm{C}$ and $500^{\circ} \mathrm{C}$ according to a recent study by Mazlan et al [42]. The differences between the degradation temperatures are explained by the differences in chemical structures, therefore; hemicelluloses which are of an amorphous structure are easily hydrolyzable [43], while cellulose which is of a more crystalline structure improves its thermal stability [44]. Highly crosslinked lignin with a high molecular weight generates very high thermal stability which makes it difficult to decompose [45].

The curves in Figure 3 which presents three main peaks confirm the results found. At $78.22^{\circ} \mathrm{C}$ (first peak) the humidity begins to volatilize. The second peak observed at $330.05^{\circ} \mathrm{C}$ in Diss curve assigned to cellulose decomposition. The last peak appears around $475^{\circ} \mathrm{C}$ in curve obtained attributed to lignin decomposition.

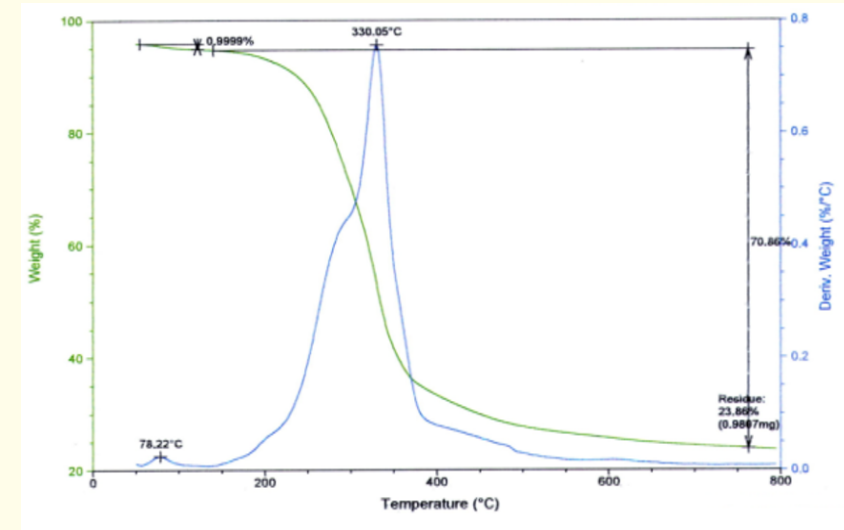

Figure 3: TGA and DTG of Diss.

\begin{tabular}{|c|c|c|c|c|c|}
\hline \multirow[b]{2}{*}{ Samples fibers } & \multicolumn{2}{|c|}{$1^{\text {st }}$ stage degradation in TGA curve } & \multicolumn{2}{|c|}{$2^{\text {nd }}$ stage degradation in TGA curve } & \multirow{2}{*}{$\begin{array}{l}\text { Residual mass \% at } \\
\mathbf{8 0 0}^{\circ} \mathrm{C}\left(\% \cdot{ }^{\circ} \mathrm{C}^{-1}\right)\end{array}$} \\
\hline & $\begin{array}{c}\text { Temperature } \\
\text { range }\left(\mathrm{T}_{1}\right)\left({ }^{\circ} \mathrm{C}\right) \\
\end{array}$ & \begin{tabular}{|c|} 
Weight \\
Loss (\%) \\
\end{tabular} & $\begin{array}{c}\text { Temperature } \\
\text { Range }\left(\mathrm{T}_{2}\right)\left({ }^{\circ} \mathrm{C}\right)\end{array}$ & \begin{tabular}{|c|} 
Weight \\
Loss (\%) \\
\end{tabular} & \\
\hline Diss & 192.54 to 280.12 & 23.57 & 280.12 to 390.01 & 47.29 & 23.86 \\
\hline
\end{tabular}

Table 4 : TGA Results of Diss.

\section{SEM image analysis}

Figure 4 shows the morphology of the Diss sample. In longitudinal section, there are defects on the surface of the fiber which prevents an appreciation of the fibrillar structure of the sample. On the other hand, in cross section, a considerably uniform circular and fibrillar porous structure is observed. However, some lignin or lignin carbohydrate complexes may be condensed on the surface of cellulose fibers [46].
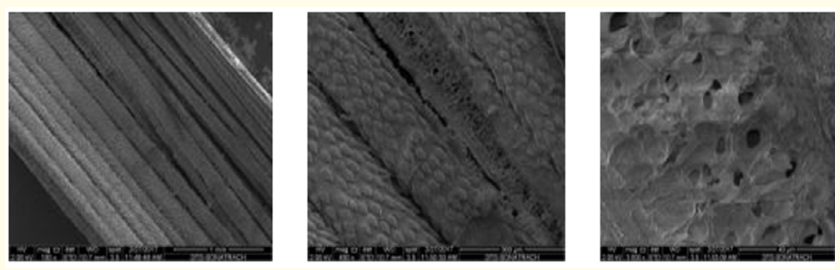

Figure 4: SEM images of Diss.

\section{Conclusion}

The physical, chemical and thermal characteristics of Diss fibers, were discussed in this study.

The chemical analysis revealed that the samples of the contain a higher quantity of extractives and a lower quantity of cellulose and hemicelluloses than wood. The results of the FTIR demonstrated a significant amount of polysaccharide associated with the bands $1200-900 \mathrm{~cm}^{-1}$. The Scanning Electron Microscopy (SEM) shows that the raw fibers have smooth and homogenous surface with highly porous texture and clearly shows the presence of longitudinally oriented unit cells with almost parallel orientations.

Obtained results indicate us, that the Diss can be an alternative non-wood raw material for pulp, paper, and hydrolysis chemistry.

\section{Bibliography}

1. Khalil A., et al. "Green composites from sustainable cellulose nanofibrils”. Carbohydrate Polymers 87 (2012): 963-979.

2. Reddy MM., et al. "Biobased plastics and bionanocomposites: Current status and future opportunities". Progress in Polymer Science 38 (2013): 1653-1689.

3. Khan A., et al. "Nanocellulose-based composites and bioactive agents for food packaging". Critical Reviews in Food Science and Nutrition 54 (2014): 163-174.

4. Belgacem MN and Gandini A. "Monomers, polymers and composites from renewable resources". Elsevier, Amsterdam (2008).

5. Ahmadzadeh A., et al. "Liquefaction of oil palm empty fruit bunch (EFB) into phenol and characterization of phenolated EFB resin". Industrial Crops and Products 30 (2009): 54-58.

6. Ali IS., et al. "Kenaffibres as reinforced for polymeric composites. A review". International Journal of Mechanical and Materials Engineering 4 (2009): 239-248.

7. Thomas S and Pothan L. "Cellulose fiber reinforced polymer composites". Old City Publishing (Philadelphia) (2009).

8. Cordeiro ON., et al. "Chemical composition and pulping of banan pseudo-streams". International journal crops and products 19 (2004): 147-154.

9. Foyle T., et al. "Compositional analysis of lignocellulosic materials: Evaluation of methods used for sugar analysis of waste paper and straw". Bioresource Technology 98 (2007): 30263036. 
10. Sorek N., et al. "The Implications of Lignocellulosic Biomass Chemical Composition for the Production of Advanced Biofuels". BioScience 64 (2014): 192-201.

11. Klemm D., et al. "Cellulose: Fascinating Biopolymer and Sustainable Raw Material”. 44 (2005): 3358-3393.

12. Moon RJ., et al. "Cellulose nanomaterials review: structure, properties and nanocomposites". Chemical Society Reviews 40 (2011): 3941-3994.

13. Fengel D and Wegener G. "Wood chemistry, ultrastructure, Reactions". Walter de Gruyter, Berlin and New York (1984).

14. Zablackis E., et al. "Characterization of the Cell-Wall Polysaccharides of Arabidopsis thaliana Leaves". Plant Physiology 107 (1995) 1129-1138.

15. Desvaux M. "Clostridium cellulolyticum: model organism of mesophilic cellulolytic clostridia”. FEMS Microbiology Review 29 (2005): 741-764.

16. Saha BC. "Hemicellulose bioconversion". Journal of Industrial Microbiology and Biotechnology 30 (2003): 279-291.

17. Laureano-Perez L., et al. "Understanding factors that limit enzymatic hydrolysis of biomass: Characterization of Pretreated Corn Stover". Applied Biochemistry and Biotechnology (2005): 121-124:1081-1099.

18. Pratima B. "Pretreatment of Lignocellulosic Biomass for Biofuel Production". Springer Briefs in Green Chemistry for Sustainability, Chapter II Structure of lignocellulosic Biomass (2016): 7-9.

19. Saijonkari-Pahkala K. "Non-wood plants as raw material for pulp and paper". Thesis Faculty Agricultural and Forest, University of helsinky in Finland (2001): 101.

20. Sridach W and Suranaree. "The Environmentally Benign Pulping Process of Non-Wood". Fibers Journal of Science and Technology 17 (2010): 105-123.

21. Plazonić I., et al. "Chemical composition of straw as an alternative material to wood raw material in fiber isolation". Drvna Industrija 67 (2016) 119-125.

22. Paiva MC., et al. "Alfa fibres: Mechanical, morphological and interfacial characterization". Composites Science and Technology 67 (2006): 1132-1138.

23. Akchiche 0 and Messaoud BK. "Esparto grass (Stipa tenacissimaL), raw material of papermaking". First part. Kimiyarastitelnovocirya, 4 (2007): 25-30.N $4 . C .25-30$.

24. Merzoud M. "Elaboration et caractérisation d'un matériau composite à base de fibres de diss dans la fabrication de la maçonnerie". Thèse de doctorat d'Etat, Université Badji Mokhtar, Algérie (2007).
25. Bourahli MEH. Caractérisation d'un composite verre/époxy. Thèse de magistère. Université Ferhat Abbas, Sétif, Algérie (2014).

26. Sellami A. Elaboration des composites cimentaires à base de fibres végétales locales (le diss): Caractérisation, Durabilité et Application au cas de la maçonnerie, Thèse de magistère. Université Badji Mokhtar-Annaba, Algérie (2015).

27. Blasi CD., et al. "Product distribution from pyrolysis of wood and agricultural residues". Industrial Engineering Chemistry Research 38 (1999): 2216-2224.

28. Sluiter A., et al. "Determination of structural carbohydrates and lignin in biomass". Laboratory analytical procedure 1617 (2008): 1-16.

29. Ouensanga A. "Variation of fiber composition in sugar cane stalks". Journal of the society of wood science and technology 21.2 (1989): 105-111.

30. Segal L., et al. "An Empirical Method for Estimating the Degree of Crystallinity of Native Cellulose Using the X-Ray Diffractometer". Textile Research Journal 29 (1959): 786-794.

31. Mcmanus WR., et al. "The physical distribution of mineral material on forage plant cell walls". Australian Journal of Agricultural Research 28 (1997): 651-662.

32. Hurter AM. "Utilization of annual plants and agricultural residues for the production of pulp and paper". Proceedings of TAPPI pulping conference. New Orleans, LA, USA Book 1 (1988): 139-160.

33. Poletto M., et al. "Native Cellulose: Structure, Characterization and Thermal Properties". Materials 7 (2014): 6105-6119.

34. Augustine OA., et al. "Compositional analysis of lignocellulosic materials: Evaluation of an economically viable method suitable for woody and non-woody biomass". American Journal of Engineering Research (AJER) 4 (2015): 14-19.

35. Yokoi H., et al. "Rapid characterization of wood extractives in wood by thermal desorption-gas chromatography in the presence of tetramethylammonium acetate". Journal of Analytical and Applied Pyrolysis 67 (2003) 191-200.

36. Ishida Y., et al. "Direct analysis of phenolic extractives in wood by thermochemolysis-gas chromatography in the presence of tetra butyl ammonium hydroxide". Journal of Analytical and Applied Pyrolysis 78 (2007): 200-206.

37. Wada M and Okano T. "Localization of I $\alpha$ and I $\beta$ phases in algal cellulose revealed by acid treatments". Cellulose 8 (2001): 183-188. 
38. Mészáros E., et al. "TG/MS, Py-GC/MS and THM-GC/MS study of the composition and thermal behavior of extractive components of Robinia pseudoacacia". Journal of Analytical and Applied Pyrolysis 79 (2007): 61-70.

39. Chen H., et al. "Qualitative and quantitative analysis of wood samples by Fourier transform infrared spectroscopy and multivariate analysis". Carbohydrate Polymers 82 (2010): 772-778.

40. Kim UJ., et al. "Thermal decomposition of native cellulose: Influence on crystallite size". Polymer Degradation and Stability 95 (2010): 778-781.

41. Åkerholm M., et al. "Characterization of the crystalline structure of cellulose using static and dynamic FT-IR spectroscopy". Carbohydrate Research 339 (2004): 569-578.

42. Mazlan MAF., et al. "Characterizations of Bio-char from Fast Pyrolysis of Meranti Wood Sawdust". Journal of Physics: Conference Series 622 (2015): 012054.

43. John MJ and Thomas S. "Biofibres and biocomposites". Carbohydrate Polymers 71 (2008): 343-364.

44. Yang H., et al. "In-Depth Investigation of Biomass Pyrolysis Based on Three Major Components: Hemicellulose, cellulose and lignin". Energy Fuels 20 (2006): 388-393.

45. Bridgwater AV. "Review of fast pyrolysis of biomass and product upgrading". Biomass and Bioenergy 38 (2012): 68-91.

46. Dhanalakshmi S., et al. "Physical Characterization of Natural Lignocellulosic Single Areca Fiber". Ciência and Tecnologia dos Materiais 27 (2015): 121-135.

\section{Assets from publication with us}

- Prompt Acknowledgement after receiving the article

- Thorough Double blinded peer review

- Rapid Publication

- Issue of Publication Certificate

- High visibility of your Published work

Website: www.actascientific.com/

Submit Article: www.actascientific.com/submission.php Email us: editor@actascientific.com

Contact us: +919182824667 